\title{
SIMULASI TEKNIK PENGKODEAN SUARA CELP (CODEBOOK EXCITED LINEAR PREDICTION) PADA SUARA LUMBA - LUMBA
}

\author{
Samuel Pesta Panangian, Herlinawati, Umi Murdika \\ Jurusan Teknik Elektro Fakultas Teknik \\ Universitas Lampung \\ Jl. Prof. Soemantri Brojonegoro No.1 Bandar Lampung 35145 \\ sagara8790@gmail.com
}

\begin{abstract}
Abstrak
Gelombang ultrasonik merupakan gelombang suara dengan frekuensi diatas $20 \mathrm{KHz}$ gelombang suara (sonik).Dewasa ini banyak peneliti menggunakan suara lumba-lumba sebagai alat bantu untuk terapi bagi anak-anak autisme.Sonar lumba-lumba pada frekuensi ultrasonik mampu melokalisasi gema yang menghasilkan cavitation dan menyebabkan sonophoresis (merangsang hormon endorkrins pada tubuh manusia), serta suara lumba-lumba dapat merangsang sistem pusat saraf (spinal dan cerebral).

Penelitian ini mensimulasikan suara lumba-lumba yang telah mengalami pemrosesan sebanyak 2 kali, suara lumbalumba mengalami proses pereduksian noise terlebih dahulu. Setelah melalui pereduksian noise selanjutnya suara lumba-lumba diproses menggunakan metode CELP (Codebook Excited Linear Prediction). Pada sintak CELP, suara lumba-lumba di proses lagi kedalam 2 bitrate yaitu bitrate $9.6 \mathrm{kbps}$ dan bitrate $16 \mathrm{kbps}$ untuk melihat hasil pemrosesan yang lebih baik. Kemudian membandingkan antara suara terapi yang beredar dipasaran dengan suara hasil penelitian dan didapat bahwa untuk suara terapi didapat range frekuensi nya dari 0-300 $\mathrm{Hz}$ sedangkan untuk suara hasil penelitian didapat bahwa range frekuensi nya sekitar 0-1000 Hz.

Kata kunci : CELP, cavitation, sonophoresis, bitrate, FFT

Abstract

Ultrasonic waves are sound waves with frequencies above $20 \mathrm{KHz}$ sound waves (Sonic). Currently, many researchers use the voice of the dolphins as a tool for the therapy of children's autism. Sonar dolphins on ultrasonic frequencies are able to localize echoes that produces cavitation and cause sonophoresis (stimulate hormone endokrins in human body), and dolphin sound can stimulate system nerve center (spinal and cerebral).

This research simulates the sound of a dolphin which has processed 2 times, the sound of dolphins experiencing noise reduction process before. After going through the noise reduction then the dolphins sound are processed using the method of CELP (Codebook Excited Linear Prediction). In CELP syntax, the sound of dolphins are processed again into 2 bitrate, $9.6 \mathrm{kbps}$ bitrate and bitrate of $16 \mathrm{kbps}$ to see the better processing results. Then compare between sound therapy with a sound research results and obtained that for sound therapy, gained his frequency range from $0-300 \mathrm{~Hz}$ as for sound research results obtained that his frequency range around 0-1000 $\mathrm{Hz}$.
\end{abstract}

Keyword : CELP, cavitation, sonophoresis, bitrate, FFT

\section{PENDAHULUAN}

Lumba-lumba mengandalkan sistem sonar yang disebut echolocation sebagai sensor utama mereka, karena akustik merupakan sarana yang paling efektif dan efisien untuk berkomunikasi pada lingkungan perairan. Lumba-lumba mentransmisikan sinyal akustik dari nasal cavity pada bagian kepala dan menerima pantulannya dari rahang bawah. Pantulan tersebut memungkinkan lumba-lumba untuk mengetahui bentuk, ukuran, tekstur dan jarak dari objek. Hal ini sangat berguna sebagai alat navigasi, untuk mencari mangsa dan menghindar dari predator.
Suara dengan durasi, panjang gelombang, amplitudo, frekuensi, interval dan pola suara yang berbeda ditransmisikan untuk tujuan yang berbeda pula.

Dewasa ini banyak peneliti menggunakan suara lumba-lumba sebagai alat bantu untuk terapi bagi anak-anak autisme. Sonar lumba-lumba pada frekuensi ultrasonik mampu melokalisasi gema yang menghasilkan cavitation dan menyebabkan sonophoresis (merangsang hormon endorkrins pada tubuh manusia). Serta suara lumba-lumba dapat merangsang sistem pusat saraf (spinal dan cerebral). 
Berdasarkan alasan diatas, perlu dilakukan penelitian Tugas Akhir yang berjudul "Simulasi Teknik Pengkodean Suara CELP (Codebook Excited Linear Prediction) Pada Suara Lumbalumba" untuk mengetahui frekuensi suara lumbalumba yang nantinya akan dijadikan sebagai alat bantu terapi bagi anak-anak autis.

\section{TINJAUAN PUSTAKA}

\subsection{Gelombang Ultrasonik}

Sebagai gelombang bunyi yang memiliki frekuensi diatas batas pendengaran manusia, atau lebih dari $20.000 \mathrm{~Hz}$. Spektrum akustik dibagi dalam tiga daerah frekuensi ditunjukan pada Gambar 2.1.

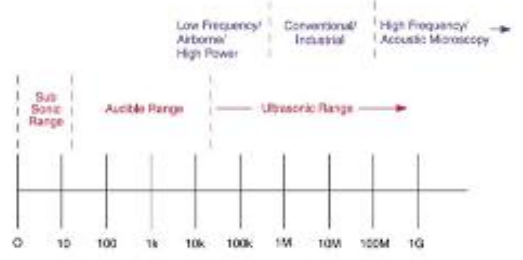

Gambar 2.1 Daerah Spektrum Frekuensi

\subsection{Sensor Ultrasonik}

Sensor ultrasonik terdiri dari dua buah transduser. Alat ini memiliki permukaan yang bergetar searah dengan arah rambat gelombang yang dipancarkan. Transduser bertindak sebagai sumber getaran yang akan diradiasikan ke medium sekelilingnya. Gambar 2.2 berikut menunjukkan penampang samping transduser ultrasonik.

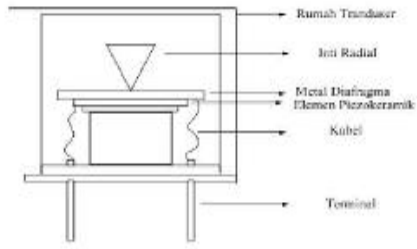

Gambar 2.2 Penampang samping transduser ultrasonik.

Adapun bagian-bagian dari transduser ini dapat dijelaskan sebagai berikut:

1. Terminal dan kabel
Fungsi dari terminal dan kabel yaitu mengalirkan arus AC pada elemen piezoelektrik.

2. Elemen piezoelektrik

Elemen ini yang merubah energi listrik menjadi energi mekanik sehingga bahan piezoelektrik bergetar dan sebaliknya.

3. Metal diafragma

Fungsi dari diafragma ini adalah sebagai pembentuk frekuensi natural dari gabungan elemen dan logam sehingga dapat beresonansi pada frekuensi yang sesuai. Jika tegangan dikenai pada logam ini maka akan menghasilkan tegangan lengkung membentuk getaran melengkung seperti pada Gambar 2.3.

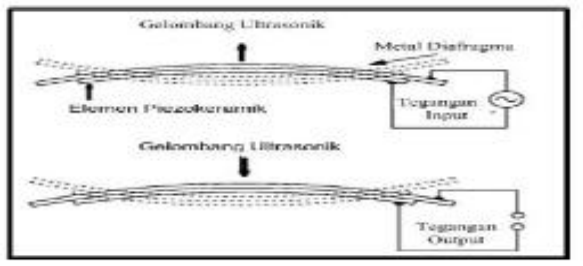

Gambar 2.3 Prinsip kerja sensor ultrasonik

Jika frekuensi listrik yang dikenakan beresonansi dengan vibrator (elemen piezoelektrik dan metal diafragma) ini maka akan menghasilkan getaran bunyi dengan frekuensi yang sesuai. Sifat ini digunakan untuk transmitter. Jika getaran bunyi yang diterima beresonansi dengan vibrator ini maka akan menghasilkan tegangan listrik yang sesuai. Sifat ini digunakan untuk receiver.

Pola radiasi gelombang ultrasonik merupakan gabungan antara gelombang bidang datar (bergerak hanya ke satu arah) dan gelombang radial (bergerak ke segala arah) seperti ditunjukkan gambar 2.4.

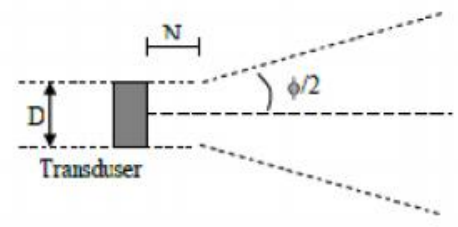

Gambar 2.4 Pola radiasi gelombang ultrasonik

Panjang daerah gelombang bidang datar mengikuti persamaan 2.2 berikut.

$$
N=\frac{D^{2}}{4 \lambda}
$$


Dimana :

$\mathrm{N}=$ Panjang daerah gelombang bidang datar

$\mathrm{D}=$ Diameter kristal piezoelektrik

$\lambda=$ Panjang gelombang ultrasonik

\subsection{Codebook Excited Linear Prediction (CELP)}

\subsubsection{Pengertian CELP}

Codebook Excited Linear Prediction (CELP) adalah algoritma speech coding yang ditemukan oleh M.R. Schroeder dan B.S. Atal pada tahun 1985 [1]. Pada saat itu, CELP kualitas nya jauh lebih baik dibandingkan dengan algoritma low bitrate yang telah lebih dahulu ada seperti, residual excited linear prediction dan linear predictive coding vocoders (LPC Vocoder). LPC Vocoder juga memiliki beberapa jenis seperti algebraic CELP, relaxed CELP, low-delay CELP, dan Vector sum excited linear prediction. [2]

Ide algoritma CELP terbagi menjadi beberapa bagian utama [3] :

1. Menggunakan source-filter model of speech production pada Linear production (LP).

2. Menggunakan adaptive dan fixed codebook sebagai input pada model LP.

3. Mengaplikasikan vector quantization (VQ).

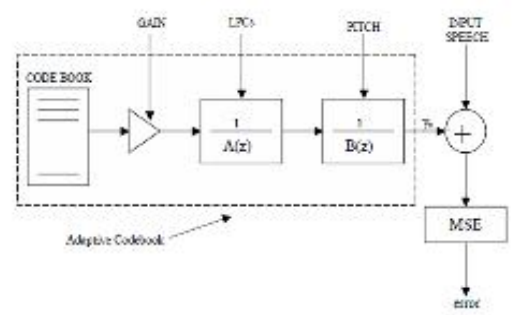

Gambar 2.5 Skema dasar CELP, meminimalkan error dengan pemilihan entry codebook terbaik.

Untuk menentukan rate pada CELP coder ditentukan oleh 2 faktor [4]:

1. Rate dari $\mathrm{VQ}=R_{V Q}=\frac{\log _{2} \mathrm{M}}{k}$

2. Bits yang berlebih perlu untuk diteruskan ke quantized Value of gain untuk setiap subframe dan koefisien LPC untuk setiap frame.

Untuk menentukan rate dari coder dalam bits per second ditentukan sebagai berikut :
$\mathrm{R}=\left(R_{V Q}+\# \text { overhead bits/sample }\right)^{*} 8000$

\subsubsection{Design dan performa Analisis dari CELP Coder}

Untuk membuat dasar dari CELP coder ada beberapa parameter yang harus diikuti [5]:

1. Ukuran Frame $\mathrm{N}=80$

2. $\mathrm{L}=10\left(10^{\text {th }}\right.$ order model $\left.\mathrm{AR}\right)$

3. Fidelity criterion - MSE

4. Dimensi $\mathrm{k}=10$ atau 5

\subsubsection{Frame dan sub-frame}

Sebuah model CELP memecah masukan menjadi 240 sampel frame, sama seperti standar LPC. Selanjutnya memproses 240 sampel frame menjadi 60 sub-frames, yang berarti setiap 1 frame memiliki 4 sub-frame. Jumlah tiap sampel per frame dan sub-frame bergantung pada versi dari CELP.

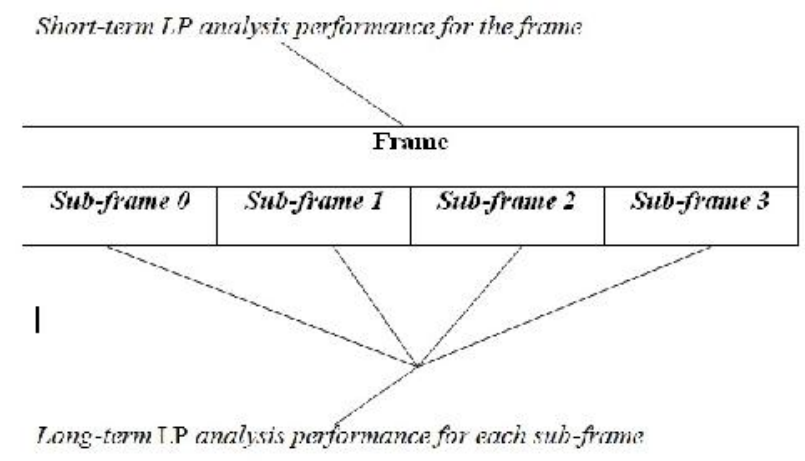

Gambar 2.6 Struktur Frame dan sub-frame

\subsubsection{Codebook}

Pengembangan selanjutnya dari teknik coding ini adalah penggunaan codebook pada sinyal eksitasi yang berbeda, bergantung pada encoder dan decoder. Encoder akan mencari sinyal yang paling pas, kemudian mengirimkan ke decoder, dimana didalam decoder ini sinyal akan diproses. Ada 2 jenis codebook, yaitu [6] :

1. Fixed codebook

2. Adaptive codebook

\subsubsection{CELP Decoder}

CELP decoder dapat dilihat pada Gambar 2.5. 


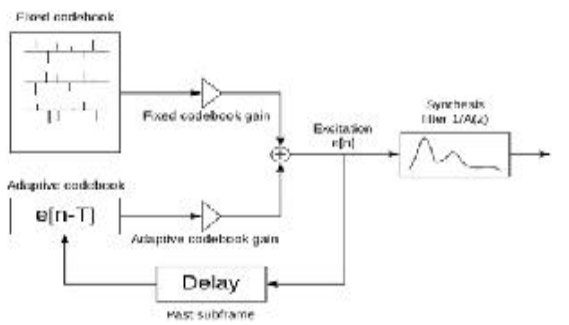

Gambar 2.5 CELP Decoder

Dari Gambar diatas terlihat bahwa excitation dihasilkan dari penambahan adaptive codebook dan stochastic (fixed) codebook.

$$
e[n]=e_{a}[n]+e_{f}[n]
$$

Dimana $e_{a}[n]$ adalah hasil adaptive codebook dan $e_{f}[n]$ adalah hasil stochastic codebook [7].

\subsubsection{Linear Prediction (LPC)}

Linear Prediction adalah dasar dari banyak teknik speech coding termasuk CELP. Prinsip dasar nya adalah menentukan sinyal $x[n]$ menggunakan kombinasi linear dari sample sebelumnya [8] :

$$
y[n]=\sum_{i-1}^{N} a_{\mathrm{i}} x[n-i]
$$

Dimana $y[n]$ adalah prediksi linear dari $x[n]$. Rumus untuk menentukan prediksi eror nya adalah sebagai berikut:

$$
e[n]=x[n]-y[n]=x[n]-\sum_{i-1}^{N} a_{\mathrm{i}} x[n-i]
$$

Tujuan dari analisis LPC adalah untuk menentukan hasil terbaik dari koefisien $a_{1}$ agar dapat meminimalisasikan fungsi quadratic yang eror.

$$
\left.E=\sum_{n=0}^{L-1} \mid E[n]\right]^{2}=\sum_{n=i}^{L-1}\left[n\left[n-\sum_{i=1}^{N} a_{i} x[n-i]\right]^{2}\right.
$$

Untuk filter orde $N$, koefisien filter $a_{1}$ dapat ditemukan dengan menyelesaikan persamaan $N$ x $N$ sistem linear $\mathbf{R a}=\mathbf{r}$, dimana

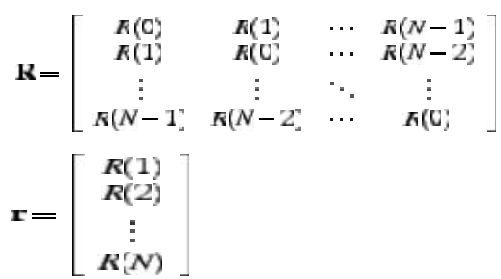

Dimana R(m), adalah auto korelasi dari sinyal $x[n]$, yang dirumuskan dalam :

$$
\boldsymbol{R}(m)=\sum_{i=0}^{N-1} x[\hat{i}] x[i-m]
$$

Karena $\mathbf{R}$ adalah toeplitz hermitian, algoritma Levinson-Durbin dapat digunakan, untuk menemukan solusi pada permasalahan $O$ $\left(N^{2}\right)$. Selain itu, algoritma tersebut juga dapat menentukan akar dari $\mathrm{A}(\mathrm{z})$, dimana $\frac{1}{A(z)}$ selalu stabil [9].

\subsection{Karakteristik Cetacea yang digunakan untuk terapi}

\subsubsection{Tursiops truncatus (Bottlenose dolphin)}

Lumba-lumba hidung botol (Tursiops truncatus) adalah jenis ordo cetacean kecil yang paling dikenal karena menghuni perairan pantai dan dipergunakan dalam pentas satwa. Memiliki ciri-ciri relative tegap, moncongnya pendek atau cukup panjang dengan ukuran yang besar dan dengan jelas terpisah dari suatu lapisan. Sirip punggung (dorsal fin) tinggi dan berujung agak bengkok seperti sabit serta muncul dari pertengahan punggung.

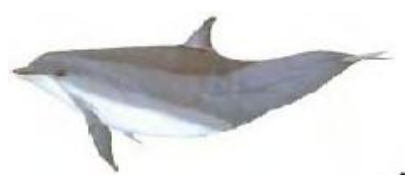

Gambar 2.7 Tursiops truncatus

\subsection{Penggunaan suara oleh lumba-lumba}

\subsubsection{Echolocation}

Echolocation adalah kemampuan binatang dalam memproduksi frekuensi yang sedang atau 
tinggi serta mendeteksi echos dari suara tersebut untuk menentukan jarak dari suatu obyek dan untuk mengenali keberadaan fisik di sekitarnya. Proses pemancaran dan penerimaan gelombang dapat dilihat pada Gambar 2.8.

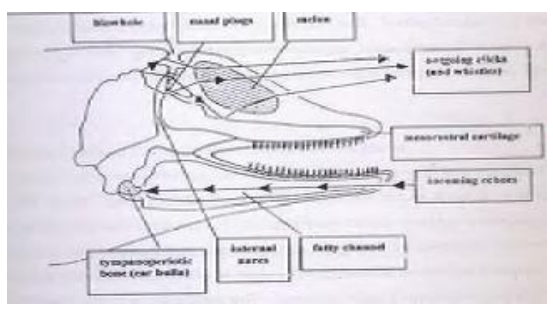

Gambar 2.8 Mekanisme produksi dan penerimaan suara pada lumba-lumba.

\section{METODE PENELITIAN}

Secara garis besar langkah-langkah yang dilakukan dalam perancangan simulasi teknik pengkodean suara codebook excited linear prediction (CELP) pada suara lumba-lumba dapat dilihat pada Gambar 3.1

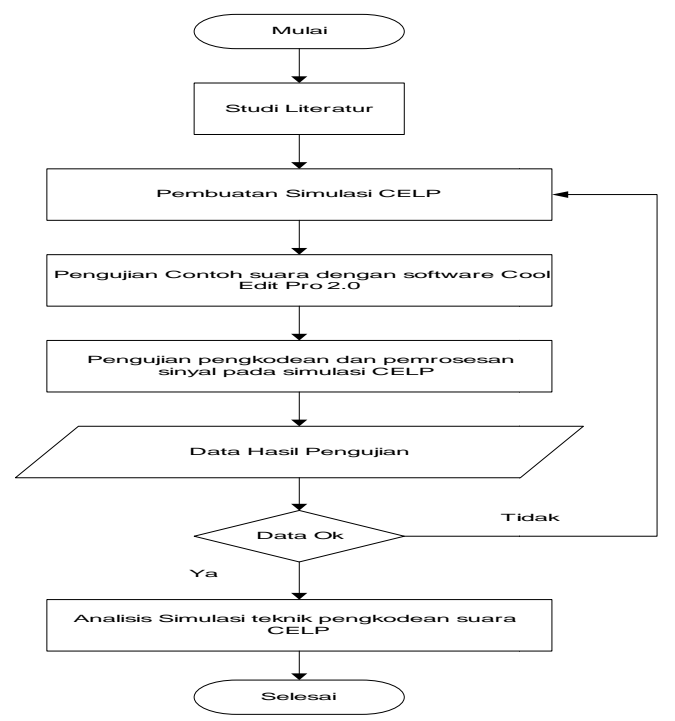

Gambar 3.1 Bagan Alir Penelitian

Pada simulasi ini, dilakukan penelitian mengenai proses pengkodean suara yang dihasilkan dengan pengkodean CELP. Parameter dari kinerja yang dibandingkan yaitu :

1. Perbandingan suara asli dengan suara pada pengkodean CELP
2. Keefektifitasan teknik pengkodean CELP untuk mengkodekan sinyal suara pada laju bit rendah.

Parameter-parameter diatas dihasilkan dengan suara keluaran yang digambarkan dengan suatu grafik yang dihasilkan dari program yang merupakan hasil simulasi dari kinerja teknik pengkodean sinyal suara CELP tersebut.

\subsection{Prosedur Penelitian}

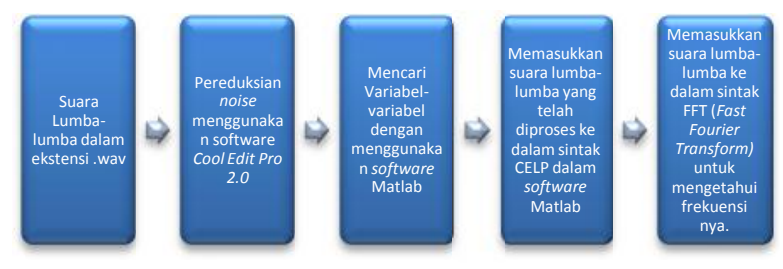

Gambar 3.2 Blok Diagram Prosedur Penelitian

Dari gambar 3.2 dapat dilihat langkahlangkah yang harus dilakukan dalam penelitian ini adalah :

1. Mengambil 2 sample suara lumba-lumba dan mengubah ekstensi kedua suara lumba-lumba menjadi ekstensi .wav

2. Mereduksi noise dengan range $25 \mathrm{~dB}$, $50 \mathrm{~dB}, 75 \mathrm{~dB}$, dan $100 \mathrm{~dB}$.

3. Menentukan range frekuensi suara lumbalumba dengan menggunakan metode CELP

\subsubsection{Menentukan Pengurangan Noise (noise reduction)}

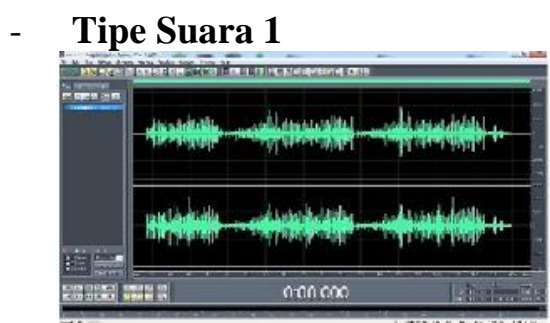

Gambar 3.3 Tipe Suara 1 sebelum noise dihilangkan.

Suara lumba-lumba yang digunakan berdurasi sekitar 4 menit. Untuk mendapatkan hasil yang lebih akurat maka pereduksian noise diambil dengan range $25 \mathrm{~Hz}, 50 \mathrm{~Hz}, 75 \mathrm{~Hz}$, dan $100 \mathrm{~Hz}$. 

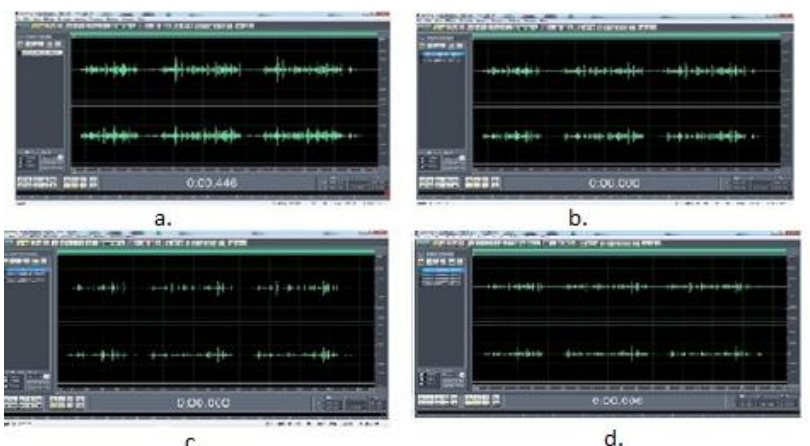

d.

Gambar 3.4 (a) Tipe Suara 1 dengan noise reduction $25 \mathrm{~dB}(\mathrm{~b})$ Tipe suara 1 dengan noise reduction $50 \mathrm{~dB}(\mathrm{c})$

Tipe suara 1 dengan noise reduction $75 \mathrm{~dB}$ (d) Tipe suara 1 dengan noise reduction $100 \mathrm{~dB}$

Dari gambar 3.4. (a) terlihat range noise reduction sebesar 25dB. Dari gambar 3.4 (a) belum tampak jelas pengelompokan suara. Pada gambar 3.4 (b) mulai terlihat pengelompokan suara menjadi 3 bagian. Dari gambar 3.4 (b) terlihat noise yang mulai menghilang. Sinyal suara asli mulai terlihat. Dari gambar 3.4 (c) noise makin ditekan. Pengelompokan gelombang makin terlihat jelas menjadi 3 bagian. Dari gambar 3.4 (d) terlihat bahwa noise semakin ditekan / dipress. Penelitian ini dibatasi reduksi noise nya hanya mencapai angka $100 \mathrm{~dB}$.

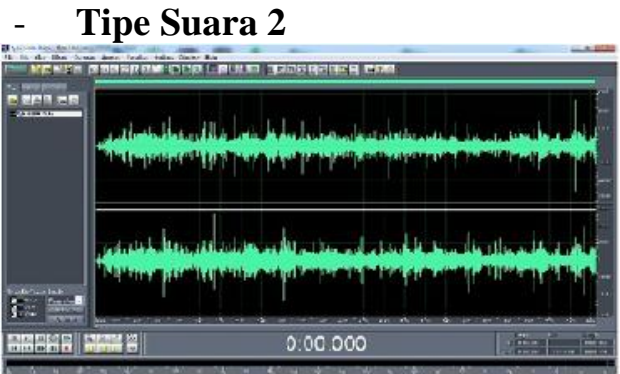

Gambar 3.5 Tipe Suara 2 sebelum noise dihilangkan

Pada tipe suara 2 yang digunakan berdurasi sekitar 8 menit. Pada gambar 3.5 diatas dapat terlihat sinyal suara asli yang belum mengalami proses noise reduction.

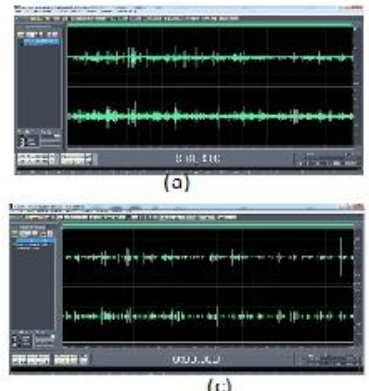

(c)

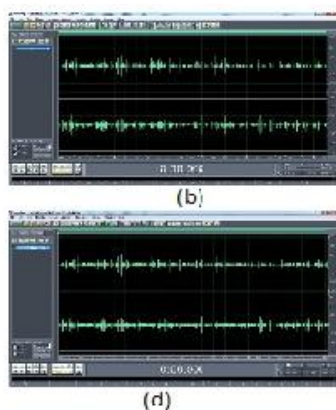

(d)
Gambar 3.6 (a) Tipe Suara 2 dengan noise reduction $25 \mathrm{~dB}$ (b) Tipe Suara 2 dengan noise reduction $50 \mathrm{~dB}$

(c) Tipe Suara 2 dengan noise reduction $75 \mathrm{~dB}$ (d)

Tipe Suara 2 dengan noise reduction $100 \mathrm{~dB}$

Pada gambar 3.6 (a) diatas terlihat sinyal suara asli yang mengalami pemrosesan noise reduction sebesar $25 \mathrm{~dB}$. Pada gambar 3.6 (b) diatas terlihat interval gelombang yang makin mengecil. Sinyal suara yang diinginkan semakin terlihat. Pada gambar 3.6 (c) diatas yang terlihat hanya pada perubahan amplitudo serta perubahan bentuk gelombang. Pada gambar 3.6 (d) diatas terlihat bahwa bentuk gelombang yang makin rapat dan amplitudo gelombangnya mengecil dan semakin mendekati nol.

\subsubsection{Proses Pengkodean CELP}

Setelah melalui proses pereduksian noise selanjutnya melakukan proses tahap ke 2 pada Matlab. Pada pemrosesan CELP suara lumbalumba tersebut mengalami perubahan bitrate. Hal ini dikarenakan untuk membuktikan bahwa suara dalam bitrate yang rendah dapat berjalan dengan baik menggunakan proses CELP, sehingga terdapat 2 bitrate yang digunakan yaitu $9.6 \mathrm{kbps}$ dengan 16 kbps. Dari kedua bitrate tersebut nanti nya akan terlihat bahwa noise akan semakin ditekan sekecil mungkin.

\subsubsection{Menentukan Range Frekuensi Lumba- lumba}

Dari hasil keluaran CELP tersebut, hasil suaranya masih dalam domain waktu (time domain), untuk mengetahui frekuensi dari hasil pengolahan suara lumba-lumba tersebut maka terlebih dahulu mengubah domain waktu menjadi domain frekuensi menggunakan fungsi FFT (Fast Fourier Transform). Jika sudah diubah maka akan terlihat besarnya frekuensi suara lumba-lumba 
hasil pengolahan CELP. Selanjutnya membandingkan antara suara lumba-lumba hasil pemrosesan dengan suara lumba-lumba terapi yang beredar dipasaran, apakah mendekati atau justru jauh berbeda.

\section{HASIL DAN PEMBAHASAN}

\subsection{Tipe Suara 1}

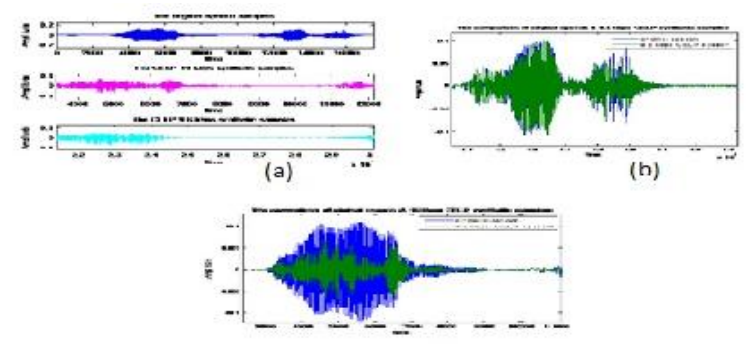

(c)

Gambar 4.2 (a) CELP untuk 25dB tipe suara 1

(b) Proses CELP dengan bitrate $9.6 \mathrm{kbps}$ untuk $25 \mathrm{~dB}$ tipe suara 1 (c) Proses CELP dengan bitrate $16 \mathrm{kbps}$ untuk $25 \mathrm{~dB}$ tipe suara 1.

Pada gambar 4.2 (a) dapat terlihat 3 bentuk gelombang suara menurut amplitudo dan waktu, gelombang suara asli / original speech samples, gelombang suara yang telah mengalami proses CELP dengan bitrate $16 \mathrm{kbps}$, dan yang terakhir gelombang suara yang mengalami proses CELP dengan bitrate $9.6 \mathrm{kbps}$. Pada gambar 4.2 (b) dengan pemrosesan CELP dengan bitrate $9.6 \mathrm{kbps}$ terlihat adanya penekanan / pression pada amplitudo gelombang. Pada gambar 4.2 (c) dengan pemrosesan CELP pada bitrate $16 \mathrm{kbps}$ amplitudo gelombang semakin ditekan jika dibandingkan dengan suara asli.
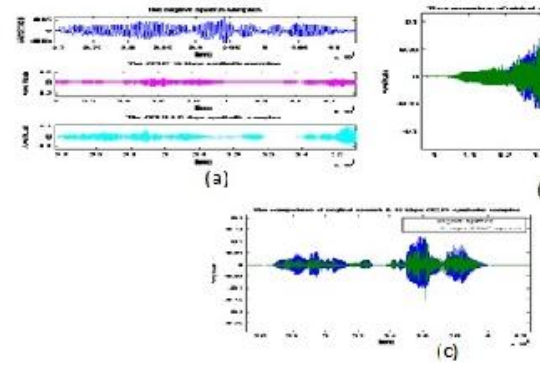

Gambar 4.3 (a) CELP untuk 50dB tipe suara 1 (b) Proses CELP dengan bitrate $9.6 \mathrm{kbps}$ untuk 50dB tipe suara 1 (c) Proses CELP dengan bitrate $16 \mathrm{kbps}$ untuk 50dB tipe suara 1.
Pada gambar 4.3 (a) dapat terlihat 3 bentuk gelombang suara menurut amplitudo dan waktu, gelombang suara asli / original speech samples, gelombang suara yang telah mengalami proses CELP dengan bitrate $16 \mathrm{kbps}$, dan yang terakhir gelombang suara yang mengalami proses CELP dengan bitrate $9.6 \mathrm{kbps}$. Pada gambar 4.3 (b) amplitudo pada proses CELP dengan bitrate 9.6 kbps lebih kecil jika dibandingkan dengan suara asli. Pada gambar 4.3 (c) amplitudo gelombang semakin ditekan jika dibandingkan dengan suara asli.

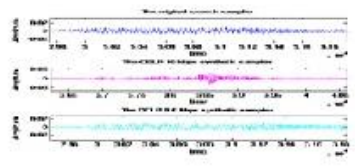

(a)

(c)

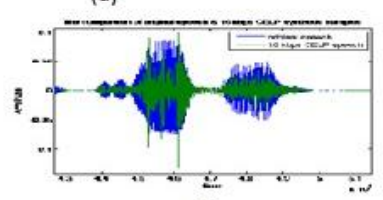

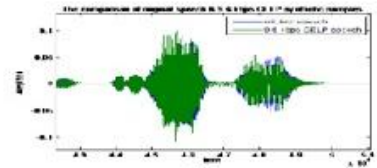

(b) (b) Proses CELP dengan bitrate $9.6 \mathrm{kbps}$ untuk $75 \mathrm{~dB}$ tipe suara 1 (c) Proses CELP dengan bitrate $16 \mathrm{kbps}$ untuk 75B tipe suara 1.

Pada gambar 4.4 (a) dapat terlihat 3 bentuk gelombang suara menurut amplitudo dan waktu, gelombang suara asli / original speech samples, gelombang suara yang telah mengalami proses CELP dengan bitrate $16 \mathrm{kbps}$, dan yang terakhir gelombang suara yang mengalami proses CELP dengan bitrate $9.6 \mathrm{kbps}$. Pada gambar 4.4 (b) dengan pemrosesan CELP dengan bitrate $9.6 \mathrm{kbps}$ terlihat adanya penekanan pada amplitudo gelombang. Amplitudo pada proses CELP dengan bitrate $9.6 \mathrm{kbps}$ lebih kecil jika dibandingkan dengan suara asli. Pada gambar 4.4 (c) dengan pemrosesan CELP pada bitrate $16 \mathrm{kbps}$ amplitudo gelombang semakin ditekan jika dibandingkan dengan suara asli. 


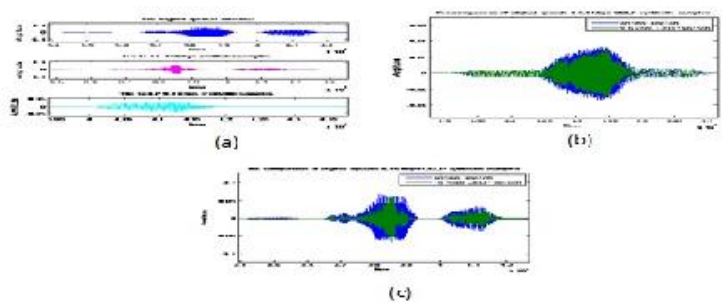

Gambar 4.5 (a) CELP untuk 100dB tipe suara 1 (b) Proses CELP dengan bitrate 9.6 kbps untuk 100dB tipe suara 1 (c) Proses CELP dengan bitrate $16 \mathrm{kbps}$ untuk $100 \mathrm{~dB}$ tipe suara 1.

Pada gambar 4.5 (a) dapat terlihat 3 bentuk gelombang suara menurut amplitudo dan waktu, gelombang suara asli / original speech samples, gelombang suara yang telah mengalami proses CELP dengan bitrate $16 \mathrm{kbps}$, dan yang terakhir gelombang suara yang mengalami proses CELP dengan bitrate 9.6 kbps. Pada gambar 4.5 (b) dengan pemrosesan CELP dengan bitrate $9.6 \mathrm{kbps}$ terlihat adanya penekanan pada amplitudo gelombang. Amplitudo pada proses CELP dengan bitrate $9.6 \mathrm{kbps}$ lebih kecil jika dibandingkan dengan suara asli. Pada gambar 4.5 (c) dengan pemrosesan CELP pada bitrate $16 \mathrm{kbps}$ amplitudo gelombang semakin ditekan jika dibandingkan dengan suara asli.

\subsection{Tipe Suara 2}

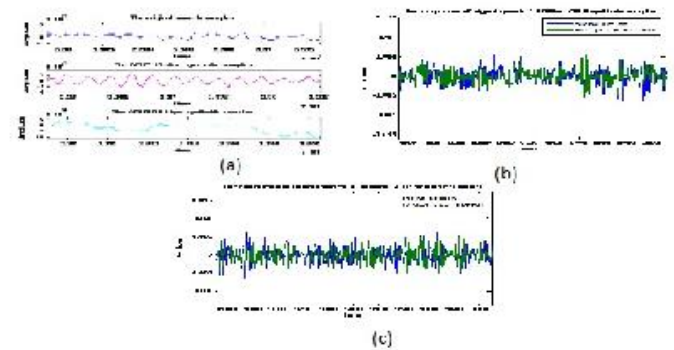

Gambar 4.6 (a) CELP untuk 25dB tipe suara 2 (b) Proses CELP dengan bitrate 9.6 kbps untuk $25 \mathrm{~dB}$ tipe suara 2 (c) Proses CELP dengan bitrate $16 \mathrm{kbps}$ untuk $25 \mathrm{~dB}$ tipe suara 2.

Pada gambar 4.6 (a) dapat terlihat 3 bentuk gelombang suara menurut amplitudo dan waktu, gelombang suara asli / original speech samples, gelombang suara yang telah mengalami proses CELP dengan bitrate $16 \mathrm{kbps}$, dan yang terakhir gelombang suara yang mengalami proses CELP dengan bitrate $9.6 \mathrm{kbps}$. Pada gambar 4.6 (b) dengan pemrosesan CELP dengan bitrate $9.6 \mathrm{kbps}$ terlihat adanya penekanan pada amplitudo gelombang. Amplitudo pada proses CELP dengan bitrate $9.6 \mathrm{kbps}$ lebih kecil jika dibandingkan dengan suara asli. Pada gambar 4.6 (c) dengan pemrosesan CELP pada bitrate $16 \mathrm{kbps}$ amplitudo gelombang semakin ditekan jika dibandingkan dengan suara asli.

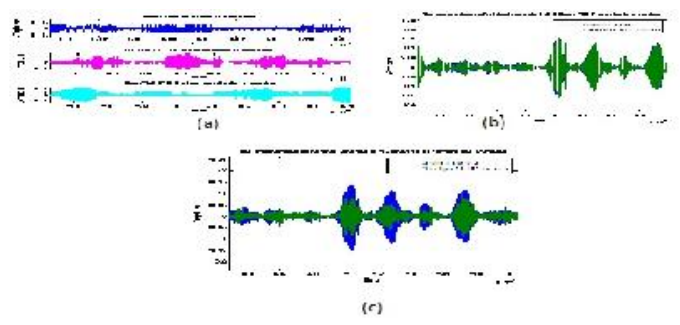

Gambar 4.7 (a) CELP untuk 50dB tipe suara 2 (b) Proses CELP dengan bitrate 9.6 kbps untuk 50dB tipe suara 2 (c) Proses CELP dengan bitrate $16 \mathrm{kbps}$ untuk $50 \mathrm{~dB}$ tipe suara 2 .

Pada gambar 4.7 (a) dapat terlihat 3 bentuk gelombang suara menurut amplitudo dan waktu, gelombang suara asli / original speech samples, gelombang suara yang telah mengalami proses CELP dengan bitrate $16 \mathrm{kbps}$, dan yang terakhir gelombang suara yang mengalami proses CELP dengan bitrate 9.6 kbps. Pada gambar 4.7 (b) dengan pemrosesan CELP dengan bitrate $9.6 \mathrm{kbps}$ terlihat adanya penekanan pada amplitudo gelombang. Amplitudo pada proses CELP dengan bitrate $9.6 \mathrm{kbps}$ lebih kecil jika dibandingkan dengan suara asli. Pada gambar 4.7 (c) dengan pemrosesan CELP pada bitrate 16 kbps amplitudo gelombang semakin ditekan jika dibandingkan dengan suara asli.

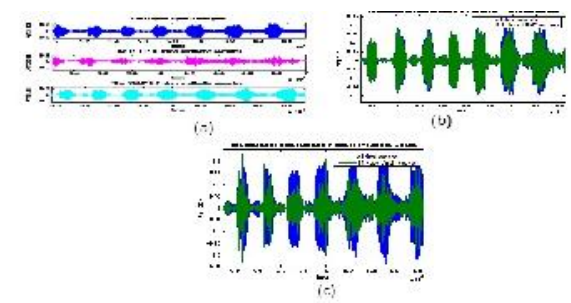

Gambar 4.8 (a) CELP untuk $75 \mathrm{~dB}$ tipe suara 2 (b) Proses CELP dengan bitrate $9.6 \mathrm{kbps}$ untuk $75 \mathrm{~dB}$ tipe suara 2 (c) Proses CELP dengan bitrate $16 \mathrm{kbps}$ untuk $75 \mathrm{~dB}$ tipe suara 2 .

Pada gambar 4.8 (a) dapat terlihat 3 bentuk gelombang suara menurut amplitudo dan waktu, gelombang suara asli / original speech samples, 
gelombang suara yang telah mengalami proses CELP dengan bitrate $16 \mathrm{kbps}$, dan yang terakhir gelombang suara yang mengalami proses CELP dengan bitrate $9.6 \mathrm{kbps}$. Pada gambar 4.8 (b) dengan pemrosesan CELP dengan bitrate $9.6 \mathrm{kbps}$ terlihat adanya penekanan pada amplitudo gelombang. Amplitudo pada proses CELP dengan bitrate $9.6 \mathrm{kbps}$ lebih kecil jika dibandingkan dengan suara asli. Pada gambar 4.8 (c) dengan pemrosesan CELP pada bitrate $16 \mathrm{kbps}$ amplitudo gelombang semakin ditekan jika dibandingkan dengan suara asli.

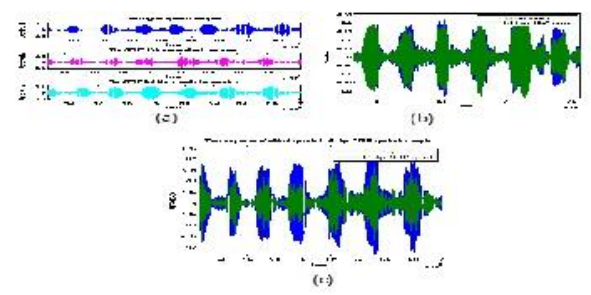

Gambar 4.9 (a) CELP untuk 100dB tipe suara 2 (b) Proses CELP dengan bitrate $9.6 \mathrm{kbps}$ untuk 100dB tipe suara 2 (c) Proses CELP dengan bitrate $16 \mathrm{kbps}$ untuk $100 \mathrm{~dB}$ tipe suara 2.

Pada gambar 4.9 (a) dapat terlihat 3 bentuk gelombang suara menurut amplitudo dan waktu, gelombang suara asli / original speech samples, gelombang suara yang telah mengalami proses CELP dengan bitrate $16 \mathrm{kbps}$, dan yang terakhir gelombang suara yang mengalami proses CELP dengan bitrate 9.6 kbps. Pada gambar 4.9 (b) dengan pemrosesan CELP dengan bitrate $9.6 \mathrm{kbps}$ terlihat adanya penekanan pada amplitudo gelombang. Amplitudo pada proses CELP dengan bitrate $9.6 \mathrm{kbps}$ lebih kecil jika dibandingkan dengan suara asli. Pada gambar 4.9 (c) dengan pemrosesan CELP pada bitrate $16 \mathrm{kbps}$ bentuk gelombang mulai terlihat perubahan.

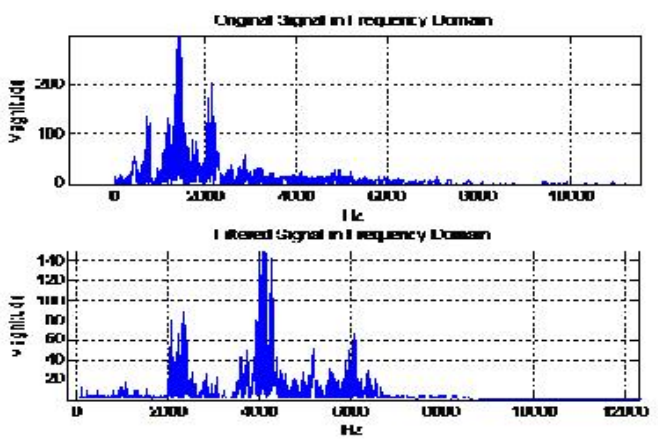

Gambar 4.10 Perbandingan sinyal suara 25dB tipe 1 dengan $25 \mathrm{~dB}$ tipe 2 .

Pada gambar 4.10 untuk gambar pertama adalah suara $25 \mathrm{~dB}$ tipe 1 sedangkan yang kedua adalah $25 \mathrm{~dB}$ untuk tipe suara 2. Pada frekuensi sekitar $2000 \mathrm{~Hz}$ maka dapat dilihat magnitude nya sekitar 60 - 80 dan pada frekuensi $4000 \mathrm{~Hz}$ magnitude nya sekitar $80-140$.

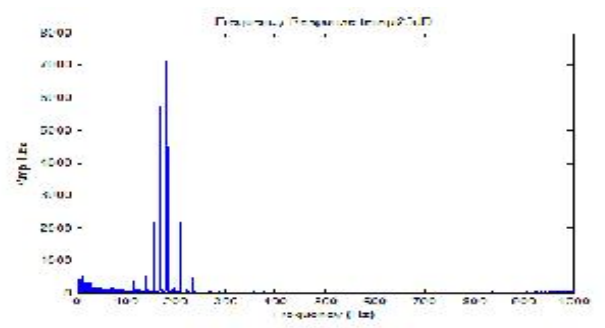

Gambar 4.11 suara terapi 25dB dalam frequency domain.

Pada gambar 4.11 diatas, terlihat range frekuensi untuk suara terapi $25 \mathrm{~dB}$. Terlihat bahwa range frekuensi nya sekitar $0-300 \mathrm{~Hz}$. Dimana ketika mencapai frekuensi $200 \mathrm{~Hz}$ mengalami amplitudo tertinggi yaitu sekitar 7000 .

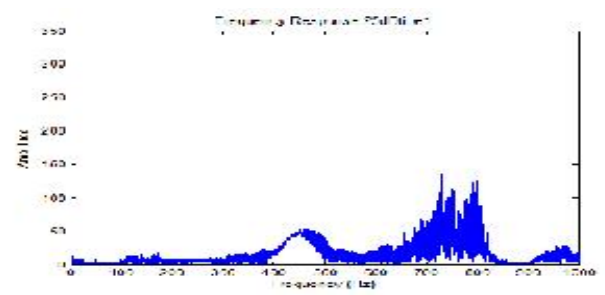

Gambar 4.12 Tipe suara 1 dengan noise reduction $25 \mathrm{~dB}$ dalam frequency domain.

Dari gambar 4.12 diatas terlihat bahwa untuk tipe suara 1 dengan noise reduction $25 \mathrm{~dB}$ memiliki range frekuensi yang cukup lebar. Range frekuensi nya $0-1000 \mathrm{~Hz}$. Amplitudo tertinggi tampak pada range frekuensi $400-500 \mathrm{~Hz}$ yang mencapai amplitudo 50 dan range frekuensi $700-$ $800 \mathrm{~Hz}$ mencapai amplitude sekitar 150 . 


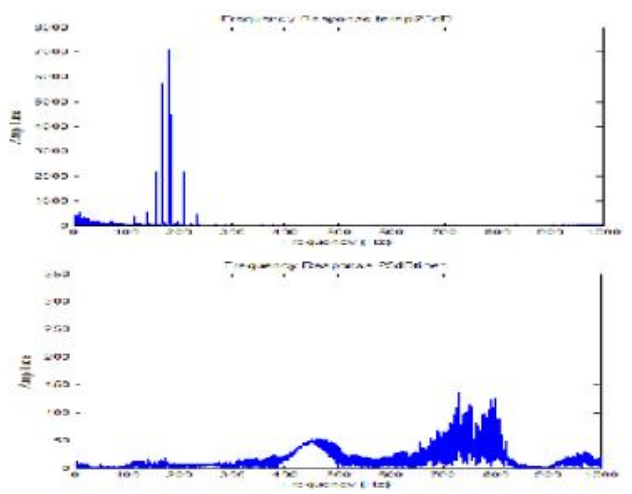

Gambar 4.13 Perbandingan frekuensi suara terapi dengan tipe suara 1.

Pada gambar pertama untuk suara terapi, range frekuensinya dari $0-1000 \mathrm{~Hz}$, sedangkan pada gambar kedua, untuk suara lumba-lumba tipe 1 dengan range frekuensi $0-1000 \mathrm{~Hz}$, mengalami amplitude yang cukup beragam, terlihat perbedaan yang cukup signifikan dari kedua gambar diatas. Pada suara terapi amplitudo tertinggi hanya pada range $100-200 \mathrm{~Hz}$, sedangkan pada suara lumba-lumba tipe 1, amplitudo tertinggi pada range $400-500 \mathrm{~Hz}$ dan $700-800 \mathrm{~Hz}$.

\section{V.SIMPULAN}

\section{A. Simpulan}

Berdasarkan simulasi dan pembahasan yang telah dilakukan, dapat disimpulkan hal-hal sebagai berikut :

1. Penelitian ini dilakukan untuk menentukan range frekuensi dua jenis suara lumba-lumba untuk dikodekan menggunakan CELP dengan bitrate $16 \mathrm{kbps}$ dan bitrate $9.6 \mathrm{kbps}$

2. Dari pengkodean yang dilakukan, suara yang dikodekan dengan bitrate 16 kbps menghasilkan suara yang jauh lebih jernih dibandingkan dengan bitrate $9.6 \mathrm{kbps}$

3. Range frekuensi yang diperoleh dari kedua jenis suara lumba-lumba yang telah diolah menggunakan pengkodean CELP didapatkan sekitar 0-300 Hz untuk jenis suara 1 dan 0$1000 \mathrm{~Hz}$ untuk jenis suara 2.

4. Terlihat ada perbedaan range frekuensi bila dibandingkan dengan suara terapi yang dijual dipasaran yang berada pada range frekuensi 0-300 $\mathrm{Hz}$, hal ini dapat mungkin terjadi dikarenakan pada suara terapi tidak mengalami proses pereduksian noise terlebih dahulu sehingga hanya merekam suara asli secara langsung, sedangkan suara hasil pengolahan telah mengalami 2 kali proses yaitu noise reduction dan pengkodean CELP.

\section{DAFTAR PUSTAKA}

[1] R. Schroeder, Manfred., S.Atal, Bishu., Code-Excited Linear Prediction (CELP): High-Quality Speech At Very Low Bit Rates. 1985.

[2] Spanias, Andreas., Venkatraman., A Simulation Tool For Introducing Algebraic CELP (ACELP) Coding Concepts In A DSP Course, Massachusetts, 2002.

[3] Chu, C.C., Kabal, P., Codebook Excited Linear Prediction of Speech : Performance in the Presence of Channel Errors. 1988.

[4] R. Schroeder, Manfred., S.Atal, Bishu., Code-Excited Linear Prediction (CELP): High-Quality Speech At Very Low Bit Rates. 1985.

[5] Kabal, P., Code Excited Linear Prediction Coding of Speech at $4.8 \mathrm{~kb} / \mathrm{s} .1987$.

[6] Kabal, P., Speech Coder: A Matlab Implementation. 2011. G. 723.1.

[7] Marc Valin., Jean., Speex: A Free Codec For Free Speech. 2006.

[8] Marc Vallin., An Enhanced Adaptive Codebook For A CELP Coder. 1994.

[9] Kumar Devalapalli, Suresh., Rangarajan, Raghuram., Venkataramanan, Ramji, Design of a CELP Speech Coder and Study of Complexity vs Quality Trade-offs for Different Codebooks. 2004

[10] Lampung, Universitas, Format Penulisan Karya Ilmiah Universitas Lampung. Universitas Lampung. Lampung. 2008.

[11]

http://reocities.com/SiliconValley/peaks/7 687/section1c.html. Diakses pada tanggal 24 November 2013

http://www.mathworks.com/matlabcentral /fileexchange/39038-celpcodec/content/CELP_done/CELP_RUN.m. Diakses pada tanggal 20 Oktober 2013 